\title{
The Avatar Effect: The Harmful Consequences of Decision-Making through a 'Separate' Entity
}

\author{
Chris Macdonald ${ }^{1 *}$ \\ ${ }^{1}$ Skylab, United Kingdom \\ *Corresponding author: Chris Macdonald: chrismacdonald@dr.com
}

Citation: Macdonald C. (2020) The Avatar Effect: The Harmful Consequences of Decision-Making through a 'Separate' Entity. Open Science Journal 5(3)

Received: $16^{\text {th }}$ February 2020

Accepted: $12^{\text {th }}$ May 2020

Published: $6^{\text {th }}$ July 2020

Copyright: (c) 2020 This is an open access article under the terms of the Creative Commons Attribution License, which permits unrestricted use, distribution, and reproduction in any medium, provided the original author and source are credited.

Funding: The author(s) received no specific funding for this work

Competing Interests: The author has declared that no competing interests exist.

\begin{abstract}
:
As we are in the midst of a global crisis, caused primarily by human activity, it is vital to ask, what leads us to make such ethically compromised decisions? This paper reveals a phenomenon that may cause an individual to loosen or lose their moral compass: the avatar effect. The case is made that there are frequent situations where individuals and groups can make decisions through - what appears to them as - a separate entity, and that through compounding underlying mechanisms, this can result in an increased sense of disconnection, compromised judgement, and harmful consequences.
\end{abstract}

Keywords: Ethics, Psychology, Economics, Cognition, Sociology, Connection, Ethical decision-making, Corporate responsibility, Business practices, Disconnecting agents, Avatar effect.

\section{Introduction}

As we are in the midst of a human-caused global crisis (Cook et al, 2013; Cook et al, 2016), it is vital to ask ourselves, what leads us to make ethicallycompromised decisions? Why do we make choices that harm the environment (Cook et al, 2013; Zhu et al, 2014; Chandrappa et al, 2015; Cook et al, 2016), others (Kaur et al, 2008; Trojan et al, 2011; Lin et al, 2018; Stone, 2019), and ourselves? (Klonsky et al, 2014; Lloyd-Richardson et al, 2015; Brådvik, 2018; Roh et al, 2018)

A uniting theme that appears in the research of harmful conduct is disconnection. For example, having connections with those around you decreases the potency of the bystander effect (Latané et al, 1969; Brody et al, 2016), fewer breaks in chains of production reduces consumer tolerance of unethical business practices (Macdonald, 2020a), and greater proximity to potential victims (Bandura, 1992; Mencl et al, 2009; Brody et al, 2016), eye contact (Valentine, 
1980; Bull et al, 1981; Cañigueral et al, 2019), or even the mere image of eyes (Baillon et al, 2012; Francey et al, 2012; Bateson et al, 2013), can decrease the likelihood of unethical decision-making.

And on a more abstract level, participants primed via word games that include connection-related terminology (Macdonald, 2019; Macdonald, 2020b), and participants primed via images of connected stick figures (Macdonald, 2020c), were shown to be less likely to make unethical choices.

Therefore, when we are subject to systems, tools, or ideas that disconnect us from one another, our ethical behavior can significantly decrease. But what about disconnection from ourselves?

Moral disentanglement is suggested to also play a significant role in unethical conduct. As Albert Bandura notes, a key component to ethical conduct is the self-regulatory mechanisms tied to personal standards (Bandura, 2001). Bandura states that in addition to not wanting others to view us in a negative light, we also have a strong fear of self-condemnation (Bandura, 2002). In other words, we internally judge our behavior as it is also important what we think of ourselves. Just as we'd like others to behave in a morally responsible manner, we'd also like ourselves be in line with that vision. We'd like to be able to respect ourselves. As a result, people tend to strive to maintain a positive self-image, even when there is no risk of being found out (Allport, 1955; Rosenberg, 1979; Mazar et al, 2008; Sachdeva et al, 2009; Barkan et al, 2012; Shalvi et al, 2015).

Thus, how we frame our behavior can play a key role in moral conduct. If a decision can be framed in a way that is deemed as justified, then the immoral behaviour can be seen as excusable in context, thus preserving a positive selfimage (Shalvi et al, 2015). Similarly, if one can absolve personal responsibility, such as deeming the situation as uncontrollable, then there is an increase in unchecked unethical conduct (Gottfredson et al, 1990; Baumeister et al, 2001; Trevino et al, 2006; Mead et al, 2009). Lower levels of guilt have also been strongly related to increased unethical behavior, again implying that a reduced sense of personal responsibility is a key underlining mechanism of unethical conduct (Karremans et al, 2005; Eisenberg, 2007; Tangney et al, 2007; Cohen et al, 2011; Cohen et al, 2012; Olthof, 2012; Xu et al, 2012; Czarna, 2014; Arli et al, 2016; Ackerman et al, 2017; Arli et al, 2017; Poless et al, 2018).

This led me to explore scenarios where one might be able to view themselves as another entity. Theoretically speaking, if one no longer viewed themselves as personally being involved in a given situation, then one could make unethical decisions without the judgment of others and themselves. In theory, this could have a compounding negative impact on morality. Someone operating as a 'separate' entity wouldn't need to be disconnected from others, or find a way to justify a situation, as from their perspective, they aren't personally involved in the situation. In other words, one might be able to enter a state of mind where they are acting through an avatar, like a video game.

\section{Online avatar}

A situation where we might see individuals temporarily view themselves as a separate entity is online, as individuals could 'become' an online avatar.

A related area, that is currently gathering attention due to the current scale of the problem, is cyberbullying (Hasebrink et al, 2009; Patchin et al, 2016; Hinduja et al, 2017; Lee et al, 2017; Fluck, 2018; Hinduja et al, 2019). By virtue 
of the medium, several compounding factors may disconnect an online avatar from others and the outside world: anonymity, the absence of rules, and a lack of monitoring (Harrison, 2015). Yet while the inherent potential for anonymity has its implications (Moore et al, 2012; Vaillancourt et al, 2017; Coe, 2018; Young et al, 2018), there are also potential consequences of pseudonymity (Adeney, 2012; Coe, 2018; Maltby et al, 2018; Arrington, 2019). That is to say that just as an online user could hide their identity, they could also create or adopt a new identity. And as a result, in addition to being less observed by the outside world, they may also be less self-critical as they become a new entity, 'separate' from themselves.

When reviewing the research on cyberbullying, we can see that it is a rather complicated challenge. It isn't simply the case that when online one is essentially the same person but with a reduced fear of getting caught. When children bully online, they feel less shame, guilt, and compassion (Menesini and Camodeca, 2008; Pozzoli and Gini, 2010). They feel as though they are doing less wrong (Gini, 2006; Perren and Gutzwiller-Helfenfinger, 2012; Menesini et al, 2013). Their perception significantly changes when they communicate as a different 'entity', and this can increase the likelihood of unethical conduct. As Bandura notes, moral control is strongest when there is a clear acknowledgment that one is personally contributing to the outcomes (Bandura, 2002).

We also have the possibility of a further compounding effect: avatar-to-avatar. In an online platform, when you act as an avatar it is often with other avatars and so there is a further disconnect. One can act with reduced fear of judgement from others, with less self-critique, and when interacting with another avatar, there may be a decreased sense of a potential real-world victim. As Bandura also notes, moral disengagement can occur through the dehumanization of potential victims (Bandura, 2002). We can find vivid examples of this throughout history, where the victims were first dehumanized by being labelled as non-human before wide-scale violence took place (Harris et al, 2011; Livingstone Smith, 2011; Neilsen, 2015; Mukasonga, 2016; Bruneau et al, 2017; Rai et al, 2017; Bastian, 2019; Calissendorff et al, 2019).

\section{Mindsets and the corporate avatar}

With an online avatar, one could argue that a sense of disconnection from others and even ourselves is somewhat apparent as we are communicating through a digital medium. However, there are also scenarios in everyday life where the avatar effect can appear in more discrete ways, with face-to-face communication.

As living beings, we Homo sapiens are entwined in a complicated web of connections. The personal mindset will be used to describe a frame of mind in which we have direct links to our most important conscious connections. For example, family is often a very important personal connection, and as a result, it is one that we'll strive to maintain. Therefore, in a personal mindset, strong connections might include mother, father, brother, sister, child, and so forth. Other key personal connections might include close friends, community, or perhaps, nature. It could also include a set of values and virtues if we deem them 
as part of our personal principles, these might include environmental sustainability, equality, compassion, patience, ethics.

As there are multiple important connections, decisions made from the personal mindset can be complicated. One might deeply consider various options, as each decision can affect the rest of the web. From this perspective, staying late at work might be avoided where possible as it could impact valued connections: children, partners, friends, values.

The term avatar mindset is used to describe the frame of mind of an avatar. If you switch to an avatar mindset, you can temporarily disable the connections of the personal mindset, and borrow a new set of connections. Rather than making decisions based upon your own set of principles and with consideration of the connections around you-humanity and the natural environment-you can instead make decisions from the perspective of a hypothetical third person, an avatar: a separate entity with different connections.

In the business world, we can often see people acting as different entities. A CEO, for example, might act as a given corporation, which may be very different to how they would act themselves. Therefore you could say that they have adopted an avatar mindset. One might also say that it is less apparent as they are still in the real, physical world. To explore this concept in greater detail, let's take a look at a case study: Shkreli.

\section{Shkreli}

In 1983, Martin Shkreli was born in Brooklyn, New York. With modest means, his working-class parents-Albanian and Croatian immigrants - worked hard to raise Martin, his brother, and his two sisters (Thomas et al, 2017). Martin started to study chemistry and teach people online after discovering that a family member was suffering from depression. Therefore, one might assume that from the perspective of his personal mindset, family is a key connection. We could also assume that art is an important connection to him as he funded an indie record label (Conti et al, 2016), collects music (Conti et al, 2016), plays the guitar ( Workman et al, 2015), and often posts select lyrics from his favorite songs on social media (McLean , 2015). One might also expect that community and compassion are key connections for him, as he was so moved by a child suffering from a rare disease, he said that he would devote himself to developing treatments (McLean, 2015).

Why then, despite the humble beginnings, and signs of sensitivity and compassion, is Martin Shkreli often referred to as the most hated man in America? (Thomas et al, 2017)

There are many underlining reasons as to why he received this label, but perhaps the most notable reason is that after purchasing the rights to Daraprim - a pill used to treat patients with HIV - he decided to raise the price by over 5000\% (Conti et al, 2016). And so, why would a man who says that he deeply cares about helping people (Conti et al, 2016) make such an unethical decision?

After studying the interviews that Shkreli gave after the incident, I found numerous clues that suggest a disconnect from his personal mindset and the adoption of an avatar mindset. To begin with, he tends to use 'we' when he defends the decision rather than 'I', even though as founder and CEO, with a very small team, the choice was ultimately his. He also regularly uses collective 
nouns as a way to speak in the third-person as though he is disconnected from himself (McLean, 2015; Conti et al, 2016). And he speaks of the company as though it were a living organism, as though it made its own decisions separate from his (Tirrell, 2015).

In a live interview with David Westin, Shkreli states that the decision was made from a cash-flow perspective (Westin et al, 2016). He goes on to state that the mission was to increase revenue, therefore he is happy with the outcome (Westin et al, 2016). During the various aftermath interviews, the only explanation he offers is money, indicating that his mindset at the time was reductive or simplified, as though other connections had been severed.

When questioned directly on his personal ethics, Shkreli never fully addresses it and instead relates the decision to what the market allows for. For example, he mentions that other companies are doing the same or worse (Tirrell, 2015), he reiterates that it was incredibly profitable (Conti et al, 2016), or simply states that it wasn't technically illegal (McLean, 2015). In the few moments when he suggests that the decision was rational, he quickly adds a caveat; such as, after stating that the cost increase was appropriate, he added, when compared to other companies (Tirrell, 2015), indicating an avatar-to-avatar perspective. He also states that, "In capitalism, you try and get the highest price" (Westin et al, 2016), "extracting as much profit as possible is the rule of law" (Conti et al, 2016), and it's "the way the world works." (Conti et al, 2016) However, he also adds that "markets are not rational." (Tirrell, 2015); further indications of personal disconnects and conflicting perspectives.

If we were to view Shkreli's decision to raise the price of HIV treatments by over $5000 \%$ from a personal perspective, with many considerations, we can see that it is uncompassionate and hurtful. It negatively affects those already suffering. However, if he were to borrow the perspective of another entity, one with far fewer considerations, and a primary focus on profit, we can see how one could justify the decision. If the choice was made with regard to whether or not the flow of money is likely to increase or decrease, then it could be viewed as the ' correct choice'. It makes business sense. Personal factors such as ethics can be disconnected from this mindset. After all, 'it's just business', 'nothing personal'.

\section{Concluding remarks}

There is a known phenomenon in psychology where individuals can adopt 'multiple-selves', leading to conflicting beliefs (Schelling, 1982; Bazerman et al, 1998; Bahl, 2005; Lester, 2012; Perlovsky, 2013; Gergó et al, 2017; Hinojosa et al, 2017). With the avatar effect, there is no conflict as the individual is operating as another entity rather than themselves. Thus they can have a new set of connections, new goals, and a new purpose.

One of the concerning things about the avatar effect is that it goes relatively unchecked. It appears to disguise the unethical and unhealthy decisions of people. For example, if Martin Shkreli were to speak in the third-person, but as himself, one might be deeply concerned. If he said, "It wasn't personal, Martin did it", then this would be a clear indication of delusion and mental illness. However, if he states, "It isn't personal, it was a business decision", then it is culturally accepted. It is loosely understood that it isn't a personal choice but rather the choice of another entity, in this case, a corporate avatar. It is therefore important for us to translate it back into reality: it is a human making a decision. While the 
entities can appear as decision-making, living organisms, in reality, they are merely a human construct.

\section{References:}

Ackerman RA, Hands AJ, Donnellan MB, Hopwood CJ, Witt EA. 2017. Experts' views regarding the conceptualization of narcissism. Journal of Personality Disorders 31: 346-361 doi.org/10.1521/pedi_2016_30_254

Adeney E. 2012. Names as Brands: Moral Rights and the 'Unreasonable" Pseudonym in Australia (April 12, 2012). Kenyon AT, Loon NW, Richardson M (eds), The Law of Reputation and Brands in the Asia Pacific, Cambridge University Press 156-177 ssrn.com/abstract=2859305

Allport GW. 1955. Becoming: Basic considerations for a psychology of personality. New Haven, CT: Yale University Press

Arli D, Leo C, Tjiptono F. 2016. Investigating the impact of guilt and shame proneness on consumer ethics: A cross national study. International Journal of Consumer Studies 40: 2-13 doi.org/10.1111/ijcs.12183

Arli D, Leo C. 2017. Why do good people do bad things? The effect of ethical ideology, guilt proneness, and self-control on consumer ethics. Asia Pacific Journal of Marketing and Logistics 29:(5) 1055-1078 doi.org/10.1108/APJML-11-2016-0218

Arrington CL. 2019. Hiding in Plain Sight: Pseudonymity and Participation in Legal Mobilization. Comparative Political Studies 52:(2) 310-341 doi.org/10.1177/0010414018774356

Bahl S. 2005. Multiple selves and the meanings they give to consumptions. Doctoral Dissertations Available from Proquest scholarworks.umass.edu/dissertations/AAI3193877

Baillon A, Asli S, Van Dolder D. 2012. On the Social Nature of Eyes: The Effect of Social Cues in Interaction and Individual Choice Tasks, Evolution and Human Behavior 34:(2) 146-154 ssrn.com/abstract $=2205072$

Bandura A. 1992. Social cognitive theory of social referencing, in: S. FEINMAN (Ed.) Social Referencing and the Social Construction of Reality in Infancy. New york: Plenum 175-208

Bandura A. 2001. Social cognitive theory: an agentic perspective, Annual Review of Psychology 52: 1-26 doi.org/10.1146/annurev.psych.52.1.1

Bandura A. 2002. Selective moral disengagement in the exercise of moral agency. Journal of Moral Education 31:(2) 101-119 https://web.stanford.edu/ kcarmel/CC_BehavChange_Course /readings /Additional\%20Resources/Bandura/bandura_moraldisengagement.pdf

Barkan R, Ayal S, Gino F, Ariely D. 2012. The pot calling the kettle black: Distancing response to ethical dissonance. Journal of Experimental Psychology 141: 757-773doi.org/10.1037/a0027588

Bastian B. 2019. A dehumanization perspective on dependence in low-satisfaction (abusive) relationships. Journal of Social and Personal Relationships 36:(5) 1421-1440 doi.org $/ 10.1177 / 0265407519835978$

Bateson M, Callow L, Holmes JR, Redmond Roche ML, Nettle D. 2013. Do images of 'watching eyes' induce behaviour that is more pro-social or more normative? A field experiment on littering. PloS one 8:(12) e82055doi.org/10.1371/journal.pone.0082055

Bazerman MH, Tenbrunsel AE, Wade-Benzoni K. 1998. Negotiating with yourself and losing: Making decisions with competing internal preferences. Academy of Management Review 23: 225-241 doi.org $/ 10.2307 / 259372$

Brådvik L. 2018. Suicide Risk and Mental Disorders. Int J Environ Res Public Health 15:(9) 2028 doi.org/10.3390/ijerph15092028

Brody N, Vangelisti AL. 2016. Bystander intervention in cyberbullying. Communication Monographs 83:(1) 94-119doi.org/10.1080/03637751.2015.1044256

Bruneau E, Kteily N. 2017. The enemy as animal: Symmetric dehumanization during asymmetric warfare. PLoS ONE 12:(7) e0181422doi.org/10.1371/journal.pone.0181422

Bull R, Gibson-Robinson E. 1981. The influences of eye-gaze, style of dress, and locality on the amounts of money donated to a charity. Human Relations 34:(10) 895905doi.org/10.1177/001872678103401005

Calissendorff L, Brosché J, Sundberg R. 2019. Dehumanization amidst massacres: An examination of Dinka-Nuer intergroup attitudes in South Sudan. Peace and Conflict: Journal of Peace Psychology 25:(1) 37-48 doi.org/10.1037/pac0000352

Cañigueral R, Hamilton A. 2019. Being watched: Effects of an audience on eye gaze and prosocial behaviour. Acta Psychologica 195: 50-63 doi.org/10.1016/j.actpsy.2019.02.002

Chandrappa R, Chandra Kulshrestha U. 2015. Major Issues of Air Pollution. Sustainable Air Pollution Management: Theory and Practice 1-48 doi.org/10.1007/978-3-319-21596-9 1

Cieciura J. 2016. A Summary of the Bystander Effect: Historical Development and Relevance in the Digital Age. Inquiries Journal 8:(11) inquiriesjournal.com/a?id=1493 
Coe P. 2018. Anonymity and Pseudonymity: Free Speech's Problem Children. Media \& Arts Law Review, Forthcoming, SSRN Jan 05 ssrn.com/abstract $=3105268$

Cohen TR, Panter AT, Turan N. 2012. Guilt Proneness and Moral Character, Current Directions in Psychological Science 21:(5) 355-359 doi.org/10.1177/0963721412454874

Cohen TR, Wolf ST, Panter AT, Insko CA. 2011. Introducing the GASP scale: A new measure of guilt and shame proneness. Journal of Personality and Social Psychology 100: 947-966 doi.org/10.1037/a0022641

Conti A, Shkreli M. 2016. Martin Shkreli on drug price hikes and playing the world's villain. Vice Jan 29 youtube.com/watch? $\mathrm{v}=2 \mathrm{PCb} 9 \mathrm{mnrU} 1 \mathrm{~g}$

Cook J, Nuccitelli D, Green SA, Richardson M, Winkler B, Painting R, Way R, Jacobs P, Skuce A. 2013. Quantifying the consensus on anthropogenic global warming in the scientific literature. Environmental Research Letters 8:(2) opscience.iop.org/article/10.1088/17489326/8/2/024024/meta

Cook J, Oreskes N, Doran PT, Anderegg WRL, Verheggen B, Maibach EW, Carlton JS, Lewandowsky S, Skuce AG, Green SA, Nuccitelli D, Jacobs P, Richardson M, Winkler B, Painting R, Rice K. 2016. Consensus on consensus: a synthesis of consensus estimates on human-caused global warming. Environmental Research Letters 11:(4) doi.org/10.1088/17489326/11/4/048002

Czarna AZ. 2014. Affective consequences of self-focus in vulnerable and grandiose narcissists. Personality and Individual Differences 60: S49 doi.org/10.1016/j.paid.2013.07.200

Eisenberg N. 2007. Empathy-related responding and prosocial behaviour. Novartis Foundation Symposium 278: 71-80 doi.org/10.1002/9780470030585.ch6

Fluck J. 2018. Investigating the Comparability of Two Multi-Item-Scales for Cyber Bullying Measurement. International journal of environmental research and public health 15:(11) 2356 doi.org/10.3390/ijerph15112356

Francey D, Bergmüller R. 2012. Images of Eyes Enhance Investments in a Real-Life Public Good. PLoS ONE 7:(5) e37397 doi.org/10.1371/journal.pone.0037397

Gergő R, László L, Zsolt D, Aniko M. 2017. Multiplicity: An Explorative Interview Study on Personal Experiences of People with Multiple Selves. Frontiers in Psychology 8 doi.org/10.3389/fpsyg.2017.00938

Gini G. 2006. Social cognition and moral cognition in bullying: What's wrong? Aggressive Behaviour 32: 528-539 doi.org/10.1002/ab.20153

Harris LT, Fiske ST. 2011. Dehumanized Perception: A Psychological Means to Facilitate Atrocities, Torture, and Genocide? Zeitschrift fur Psychologie 219:(3) 175-181 doi.org/10.1027/2151$2604 / \mathrm{a} 000065$

Harrison T. 2015. Virtuous reality: moral theory and research into cyber-bullying. Ethics Inf Technol 17: 275 doi.org/10.1007/s10676-015-9382-9

Hasebrink U, Livingstone S, Haddon L, Olafsson K. 2009. Comparing children's online opportunities and risks across Europe: Cross-national comparisons for EU Kids Online (2nd ed.). Deliverable D3.2, LSE, London, EU Kids Online. Accessed June 17, 2014 from http://eprints.lse.ac.uk/24368/1/D3.2_Report-Cross_national_comparisons-2nd-edition.pdf

Hinduja S, Patchin JW. 2017. Cultivating youth resilience to prevent bullying and cyberbullying victimization. Child Abuse \& Neglect 73: 51-62 doi.org/10.1016/j.chiabu.2017.09.010

Hinduja S, Patchin JW. 2019. Connecting Adolescent Suicide to the Severity of Bullying and Cyberbullying. Journal of School Violence 18:(3) 333-346 doi.org/10.1080/15388220.2018.1492417

Hinojosa AS, Gardner WL, Walker HJ, Cogliser C, Gullifor D. 2017. A Review of Cognitive Dissonance Theory in Management Research: Opportunities for Further Development. Journal of Management 43:(1) 170-199 doi.org/10.1177/0149206316668236

Karremans JC, Van Lange PA, Holland RW. 2005. Forgiveness and its associations with prosocial thinking, feeling, and doing beyond the relationship with the offender. Personality and Social Psychology Bulletin 31: 1315-1326 doi.org/10.1177/0146167205274892

Kaur R, Garg S. 2008. Addressing domestic violence against women: an unfinished agenda. Indian journal of community medicine : official publication of Indian Association of Preventive \& Social Medicine 33:(2) 73-76 doi.org/10.4103/0970-0218.40871

Kish-Gephart JJ, Harrison DA, Trevino LK. 2010. Bad apples, bad cases, and bad barrels: Metaanalytic evidence about sources of unethical decisions at work. Journal of Applied Psychology 95: 1-31 doi.org/10.1037/a0017103

Klonsky ED, Victor SE, Saffer BY. 2014. Nonsuicidal self-injury: what we know, and what we need to know. Canadian journal of psychiatry. Revue canadienne de psychiatrie 59:(11) 565-568 doi.org/10.1177/070674371405901101

Latané B, Darley J. 1969. Bystander "Apathy". American Scientist 57:(2) 244-268 jstor.org/stable/27828530 
Lee J, Abell N, Holmes JL. 2017. Validation of Measures of Cyberbullying Perpetration and Victimization in Emerging Adulthood. Research on Social Work Practice 27:(4) 456-467 doi.org/10.1177/1049731515578535

Lester D. 2012. A Multiple Self Theory of the Mind. Comprehensive Psychology 1 doi.org/10.2466/02.09.28.CP.1.5

Lin P-I, Fei L, Barzman D, Hossain M. 2018. What have we learned from the time trend of mass shootings in the U.S.? PLoS ONE 13(10): e0204722 doi.org/10.1371/journal.pone.0204722

Livingstone Smith D. 2011. Less Than Human. New York: St Martin's Press

Lloyd-Richardson EE, Lewis SP, Whitlock JL, Rodham K, Schatten HT. 2015. Research with adolescents who engage in non-suicidal self-injury: ethical considerations and challenges. Child and adolescent psychiatry and mental health 9:(37) doi.org/10.1186/s13034-015-0071-6

Macdonald C. 2019. Money, a disconnecting agent: Reminders of money trigger a feeling of disconnection which increases the likelihood of unethical decisions. Open Science Journal 4:(1) 1-10 doi.org/10.23954/osj.v4i1.2200

Macdonald C. 2020a. The Middleman Effect: The ethical consequences of paying others to act on one's behalf. Open Science Journal 5:(1) 1-10 doi.org/10.23954/osj.v5i1.2377

Macdonald C. 2020b. Lexicon connection priming and ethics: As our sense of human connection decreases, so too does our ethical decision-making. The Open Science Journal 5:(1) 1-7 doi.org/10.23954/osj.v5i1.2276

Macdonald C. 2020c. Graphical connection priming and ethics: As our sense of human connection decreases, so too does our ethical decision-making. The Open Science Journal 5:(1) 1-6 doi.org/10.23954/osj.v5i1.2275

Maltby S, Thornham H, Bennett D. 2018. Beyond 'pseudonymity': The sociotechnical structure of online military forums. New Media \& Society 20:(5) 1773-1791 doi.org/10.1177/1461444817707273

Mazar N, Amir O, Ariely D. 2008. The dishonesty of honest people: A theory of self-concept maintenance. Journal of Marketing Research 45: 633-644 doi.org/10.1509/jmkr.45.6.633

McLean B. 2015. Everything you know about martin shkreli is wrong-or is it? Vanity Fair Dec 18 vanityfair.com/news/2015/12/martin-shkreli-pharmaceuticals-ceo-interview

Mencl J, May DR. 2009. The Effects of Proximity and Empathy on Ethical Decision-Making: An Exploratory Investigation. J Bus Ethics 85: 201-226 doi.org/10.1007/s10551-008-9765-5

Menesini E, Camodeca M. 2008. Shame and guilt as behaviour regulators: Relationships with bullying, victimization and prosocial behaviour. British Journal of Developmental Psychology 26:(2) 183-196 doi.org/10.1348/026151007X205281

Menesini E, Nocentini A, Camodeca M. 2013. Morality, values, traditional bullying, and cyberbullying in adolescence. The British Journal of Developmental Psychology 31:(1) 1-14 doi.org/10.1111/j.2044-835X.2011.02066.x

Moore MJ, Nakano T, Enomoto A, Suda T. 2012. Anonymity and roles associated with aggressive posts in an online forum. Computers in Human Behavior 28: 861-867 doi.org/10.1016/j.chb.2011.12.005

Mukasonga S. 2016. Cockroaches. New York: Archipelago Books

Neilsen RS. 2015. 'Toxification' as a more precise early warning sign for genocide than dehumanization? An emerging research agenda. Genocide Studies and Prevention: An International Journal 9:(1) 83-95 dx.doi.org/10.5038/1911-9933.9.1.1277

Olthof T. 2012. Anticipated feelings of guilt and shame as predictors of early adolescents' antisocial and prosocial interpersonal behaviour. European Journal of Developmental Psychology 9: 371388 doi.org/10.1080/17405629.2012.680300

Patchin JW, Hinduja S. 2016. Cyberbullying data. Cyberbullying Research Center cyberbullying.org/2016-cyberbullying-data

Perlovsky L. 2013. A challenge to human evolution-cognitive dissonance. Frontiers in psychology 4: 179 doi.org/10.3389/fpsyg.2013.00179

Perren S, Gutzwiller-Helfenfinger E. 2012. Cyberbullying and traditional bullying in adolescence: Differential roles of moral disengagement, moral emotions, and moral values. European Journal of Developmental Psychology 9: 195-209 doi.org/10.1080/17405629.2011.643168

Poless PG, Torstveit L, Lugo RG, Andreassen M, Sütterlin S. 2018. Guilt and Proneness to Shame: Unethical Behaviour in Vulnerable and Grandiose Narcissism. Europe's journal of psychology 14:(1) 28-43doi.org/10.5964/ejop.v14i1.1355

Pozzoli T, Gini G. 2010. Active defending and passive bystanding behavior in bullying: The role of personal characteristics and perceived peer pressure. Journal of Abnormal Child Psychology 38: 815-827 doi.org/10.1007/s10802-010-9399-9

Rai TS, Valdesolo P, Graham J. 2017. Dehumanization increases instrumental violence. Proceedings of the National Academy of Sciences 114:(32) 8511-8516 doi.org/10.1073/pnas.1705238114

Roh BR, Jung EH, Hong HJ. 2018. A Comparative Study of Suicide Rates among 10-19-Year-Olds in 29 OECD Countries. Psychiatry investigation 15:(4) 376-383 doi.org/10.30773/pi.2017.08.02

Rosenberg M. 1979. Conceiving the self. New York, NY: Basic Books 
Sachdeva S, Iliev R, Medin DL. 2009. Sinning saints and saintly sinners: The paradox of moral selfregulation. Psychological Science 20:(4) 523-528 doi.org/10.1111/j.1467-9280.2009.02326.x

Schelling TC. 1982. Ethics, law, and the exercise of self-command. Boston, MA: Harvard Institute of Economic Research

Shalvi S, Gino F, Barkan R, Ayal S. 2015. Self-Serving Justifications: Doing Wrong and Feeling Moral. Current Directions in Psychological Science 24:(2) 125-130 doi.org/10.1177/0963721414553264

Stone L. 2019. Quantifying the Holocaust: Hyperintense kill rates during the Nazi genocide Science Advances 5:(1)doi.org/10.1126/sciadv.aau7292

Tangney JP, Stuewig J, Mashek DJ. 2007. Moral emotions and moral behavior. Annual Review of Psychology 58: 345-372 doi.org/10.1146/annurev.psych.56.091103.070145

Tenbrunsel AE, Smith-Crowe K. 2008. Ethical decision making: Where we've been and where we're going. The Academy of Management Annals 2: 545-607 doi.org/10.1080/19416520802211677

Tenbrunsel AE, Smith-Crowe K, Umphress EE. 2003. Building houses on rocks: The role of the ethical infrastructure in organizations. Social Justice Research 16: 285-307 doi.org/10.1023/A:1025992813613

Thomas Z, Swift T. 2017. Who is Martin Shkreli - 'the most hated man in America'? BBC News, Washington Aug 4 bbc.com/news/world-us-canada-34331761

Tirrell M, Shkreli M. 2015. Turing CEO martin shkreli talks 5000\% drug price hike. CNBC Sep 23 youtube.com $/$ watch? $\mathrm{v}=\mathrm{L}-\mathrm{U} 1 \mathrm{MMa} 0 \mathrm{SH}$

Trojan C, Salfati CG. 2011. Linking Criminal History to Crime Scene Behavior in Single-Victim and Serial Homicide: Implications for Offender Profiling Research. Homicide Studies 15:(1) 3-31 doi.org/10.1177/1088767910397281

Vaillancourt T, Faris R, Mishna F. 2017. Cyberbullying in Children and Youth: Implications for Health and Clinical Practice. The Canadian Journal of Psychiatry 62:(6) 368-373 doi.org/10.1177/0706743716684791

Valentine ME. 1980. The attenuating influence of gaze upon the bystander intervention effect. Journal of Social Psychology 111:(2) 197psycnet.apa.org/record/1981-25777-001

Westin D, Shkreli M. 2016. Shkreli: price increase has stuck, happy with that. Bloomberg Dec 23 youtube.com/watch? $\mathrm{v}=\mathrm{gRA} 8 \times 3 \mathrm{wlY} 2 \mathrm{~g}$

Workman K, LaForge P. 2015. What happened when a teenager joined martin shkreli on a live stream. The New York Times December 17 nytimes.com/2015/12/17/business/what-happenedwhen-a-teenager-joined-martin-shkreli-on-a-live-stream.html

Xu H, Bègue L, Bushman BJ. 2012. Too fatigued to care: Ego depletion, guilt, and prosocial behavior. Journal of Experimental Social Psychology 48:(5) 1183-1186 doi.org/10.1016/j.jesp.2012.03.007

Young R, Miles S, Alhabash S. 2018. Attacks by Anons: A Content Analysis of Aggressive Posts, Victim Responses, and Bystander Interventions on a Social Media Site. Social Media + Society doi.org/10.1177/2056305118762444

Zhu S, Zhang H, Liu R, Cao Y, Zhang G. 2014. Comparison of sampling designs for estimating deforestation from landsat TM and MODIS imagery: a case study in Mato Grosso, Brazil. The Scientific World Journal 919456 doi.org/10.1155/2014/919456 